\title{
"SAÚDE PARA DOENÇA" OU PATOLOGIZAÇÃo DA SAÚDE? ${ }^{12}$
}

\author{
Marcelo Simões Mendes ${ }^{3}$ \\ Universidade Estadual de Campinas, Campinas-SP,Brasil
}

Apesar de sua primeira versão ter sido escrita na década de 40 do século passado, a obra de Georges Canguilhem carrega uma autenticidade tão representativa que seus desdobramentos ainda não conhecem os limites da temporalidade. O arcabouço teórico, assim como as discussões realizadas em sua tese de doutorado - intitulada de "O normal e o patológico" - funcionou como um marco referencial em torno das questões que permeiam não apenas o contexto da saúde em sua dimensão tradicional, mas de toda uma trajetória histórica que discute como o estado "normal" do ser humano se construiu a partir de sua condição "patológica", ou melhor, desta relação.

$\mathrm{Na}$ primeira parte de sua obra, as discussões convergem para uma perspectiva acerca do binômio normal-patológico sob o aspecto quantitativo desta relação. Afinal, seria o estado patológico apenas uma modificação quantitativa dos níveis que configuram o estado normal? A partir desta indagação, a designação do patológico como condição 'normal' assume uma representação em que a condição de doente se afirma diante dos prefixos hiper ou hipo. Sob este princípio, estar com determinada função aquém dos níveis "normais" ou a eles sobreposta configura um sujeito enfermo.

O autor comenta Augusto Comte a partir da análise realizada pelo filósofo sobre o trabalho de Broussais. Neste empenho, Broussais teria se consagrado ao afirmar que as doenças seriam apenas sintomas, uma vez que a condição patológica apenas poderia se manifestar se um órgão ou tecido tivesse sido lesionado, ou, em suas palavras: "no [caso de] excesso ou falta de excitação dos diversos tecidos abaixo ou acima do grau que constitui o estado normal" (p. 16)

As concepções de R. Leriche apontam importantes contribuições para as discussões a respeito do binômio saúde-doença. Canguilhem aponta que, para Leriche, a saúde seria "a vida nos silêncio dos órgãos", e a doença, "aquilo que perturba os homens no exercício normal de sua vida e em suas ocupações e, sobretudo, aquilo que os faz sofrer" (p. 53).

As concepções de Leriche trazem à tona algumas discussões que permeiam o contexto contemporâneo de saúde, especialmente no Brasil. Com o cuidado de não realizar direcionamentos simplistas e superficiais, mas ao mesmo tempo polêmicos e necessários, construímos algumas indagações: Quanto o sujeito por trás da 'doença' se encontra 'engessado' ou mesmo oculto? Silenciar os órgãos não seria distanciar o sujeito de suas responsabilidades e ofuscar seu protagonismo em seu processo de tratamento? Deixar de 'perturbar' o homem não seria isolá-lo das adversidades que constroem a sociedade e que, por vezes, permeiam sua vitalidade?

Mais adiante, na segunda parte de sua obra, Canguilhem discute a questão do normal e do patológico segundo a concepção de algumas ciências. Inicialmente a discussão é feita a partir da psiquiatria. Neste momento, a doença mental assume um dilema: como compreender a experiência vivida pelo sujeito

1 Resenha da obra: Canguilhem, G. (2011). O normal e o patológico. 7 ed. rev. ( M. T. R. C. Barrocas, Trad.). Rio de Janeiro: Forense Universitária.

2 Apoio e financiamento: Coordenação de Aperfeiçoamento de Pessoal de Nível Superior (CAPES).

3 Endereço para correspondência: Rua Barão Geraldo de Resende, 282, Conjunto 23 - Bairro Botafogo - CEP 13.020-440 - Campinas-SP, Brasil.E-mail: m_smendes@yahoo.com.br 
doente mental se os seus relatos não passam de interpretações que este faz de seu estado patológico? Para muitos médicos da época e até da atualidade, isto seria impossível, já que estes sujeitos não dispõem de conceitos adequados.

Esta passagem apresentada por Canguilhem sobre como a psiquiatria apresentava suas compreensões acerca do estado "enfermo" do sujeito nos chama a atenção para algumas reflexões. Mais uma vez, torna-se necessário apontar o cuidado para as considerações sobre as enfermidades mentais, uma vez que muitas vezes elas apresentam uma complexidade notória e específica a cada sujeito. Ainda assim, ao transportarmos do século passado para os tempos pós-modernos a afirmação de que não se deve considerar a experiência do sujeito, torna-se nítida a sensação de que ela é muito atual. Os protocolos médicos têm tirado, cada vez mais, um detalhe que para muitos pode passar despercebido: a voz do sujeito.

Seguindo adiante, em sua obra Canguilhem faz uma reflexão crítica a respeito dos conceitos normal, amomalia, doença experimental. Tais reflexões abrangem desde as definições de dicionários até as que se referem diretamente ao campo da medicina portanto, da saúde. Estas discussões estão ligadas ao capítulo em que o autor discute a doença, cura e saúde. Nesse momento Canguilhem pontua a difícil tarefa de encontrar as fronteiras de onde a termina a saúde e começa a doença, e vice-versa.

Quando discute o estado patológico a partir de como a concepção de saúde e doença estaria atrelada à presença e ausência de normas, respectivamente, o autor defende outro ponto de vista para esta concepção: "A doença é ainda uma norma de vida, mas uma norma inferior, no sentido que não tolerar nenhum desvio das condições em que é válida, por ser incapaz em se transformar em outra norma" (p. 127).

No fechamento deste tópico Canguilhem defende que para julgar o estado normal e o patológico seria necessário considerar o ser humano para além de sua condição vegetativa, uma vez que é possível viver com muitas malformações ou afecções. Desta forma, em última instância, se estivéssemos adaptados a circunstâncias adversas, em que nada pudéssemos fazer ou em que sempre pudéssemos fazer algo, estaríamos em uma condição normal compatível com as prerrogativas da vida.

A última parte da obra de Georges Canguilhem trata de uma experiência original e inovadora. Passados vinte anos da conclusão de sua tese de doutorado, o filósofo francês apresenta uma "reedição" dela, ou melhor, discute alguns pontos que julgava importantes e sobre os quais aponta ter passado por mudanças em seus pontos de vista. Cabe ressaltar um importante apontamento deste autor acerca da ciência médica da época (quase meio século atrás) que encontra fortes indícios de existência nos tempos pós-modernos. Nas palavras do autor:

Apesar de poder haver dúvida sobre o
modo pelo qual o corpo foi danificado,
não há nenhuma dúvida sobre a forma
a qual se deve restaurá-lo... A ciência
médica se contenta com o corpo
humano normal e procura apenas
restaurá-lo (Canguilhem, 2011, p. 206)

O mais intrigante desta afirmação é que, mesmo depois de quase 50 anos e de vivenciarmos grandes avanços no campo do diagnóstico de enfermidades, o modelo médico parece ainda privilegiar o "normal" e tratar o "anormal" ou "patológico", esquecendo-se, por vezes, da conjuntura que formam estes conceitos.

Como apontado no início deste estudo, a obra de Canguilhem apresenta uma contribuição considerável para o campo de discussão em que se situa o binômio saúdedoença ou normal-patológico; entretanto, em face da complexidade que o conceito de saúde apresenta atualmente, que não apenas aquele pressuposto pela Organização Mundial de Saúde como um estado completo de bemestar físico, mental e social..., esta discussão ainda encontra muito espaço para ampliar o escopo de considerações que o tema suscita e necessita. Desta forma, torna-se ainda necessário indagar se a construção histórica deste binômio contribuiu mais para classificar, rotular e assim estigmatizar os processos de adoecimento do que para uma compreensão mais ampla e com possibilidades de diálogo entre as diversas áreas que compõem o entendimento acerca da saúde que não apenas a biologia, fisiologia e outras da supremacia médica. 


\section{REFERÊNCIAS}

Canguilhem, G. (2011). O normal e o patológico. 7 ed. rev. Trad. Maria Thereza R. C. Barrocas. Rio de Aceito em 15/12/2013 Janeiro: Forense Universitária.

Marcelo Simões Mendes: mestre em Educação pela Faculdade de Educação da UNICAMP na área de Psicologia Educacional, doutorando pela Faculdade de Ciências Médicas da UNICAMP na área de Ciências Sociais em Saúde. 